\title{
Pengetahuan Pasien yang Menggunakan Terapi Komplementer Obat Tradisional tentang Perawatan Hipertensi di Puskesmas Pejeruk Tahun 2019
}

\author{
Ni Putu Sumartini ${ }^{1(\mathrm{CA})}$, Dewi Purnamawati ${ }^{2}$, Ni Ketut Sumiati ${ }^{3}$ \\ 1(CA) Jurusan Keperawatan, Poltekkes Kemenkes Mataram, Indonesia; arjunprabhata@gmail.com \\ ${ }^{2}$ Jurusan Keperawatan, Poltekkes Kemenkes Mataram, Indonesia; dewiwahid99@gmail.com \\ ${ }^{3}$ Jurusan Keperawatan, Poltekkes Kemenkes Mataram, Indonesia; agungmanik1997@gmail.com
}

\begin{abstract}
Hypertension is condition when the blood pressure is increased upper the normal value. Data from National Center of Health Statistics (NCHC, 2017), the prevalence of hypertension in the population aged $\geq 18$ years in the United States in 2015-2016 was $29.0 \%$, with an unknown cause in about $90-95 \%$ of cases. According to Suranti (2017) estimated that approximately $80 \%$ the increased of hypertension cases will advance become 1,15 billion in 2025. This study purposed to know the patients's knowledge about hypertension treatment. This study's design was descriptive. The population were hypertensive patients who underwent complementary therapy of traditional medicine with 33 patients at the Pejeruk Health Center. Sampling uses is non probability sampling with the Total Sampling method. In collecting the respondents' data the researcher using questionnaire sheets with direct interviews. This study showed that from 33 hypertensive respondents who underwent complementary therapy in traditional medicine at Pejeruk Health Center in 2019, most of the respondents's knowledge of hypertension treatment is in good category (57.6\%). In conclusions, the respondents's knowledge of hypertension treatment is included in the good category. The writer suggested that Pejeruk Primary Health Center needs to maintain cooperation with the society and the other health institution by conducting the disease prevention as early as possible, specifically hypertension treatment with the Complementary therapy of traditional medicine must be informed to the society through counseling, internet and mass media.
\end{abstract}

\section{Keywords: knowledge, treatment, hypertension}

\begin{abstract}
ABSTRAK
Hipertensi adalah keadaan meningkatnya tekanan darah melebihi nilai normal. Data yang diperoleh dari National Center of Health Statistics (NCHC, 2017), prevalensi hipertensi pada penduduk umur $\geq 18$ tahun di Amerika Serikat pada tahun 2015-2016 sebesar 29,0\%, dengan penyebab yang tidak diketahui sekitar 90-95\% kasus. Suranti (2017) memperkirakan kenaikan kasus hipertensi sekitar 80\% terutama terjadi di negara berkembang dan pada tahun 2025 menjadi 1,15 milyar jika dibandingkan 639 juta kasus di tahun 2000 (Ardiansyah, 2012). Salah satu upaya yang sudah dilakukan pemerintah yaitu melalui edukasi yang lebih intensif tentang pentingnya perawatan hipertensi dengan pengobatan tradisional melalui program, "Jamu Expo". Pada kegiatan pelayanan jamu, peserta program terapi komplementer ini dilakukan pemeriksaan kesehatan terlebih dahulu disertai dengan konsultasi kesehatan, pemberian pendidikan kesehatan (penkes) dan cara menerapkan terapi komplementer obat tradisional. Penelitian ini bertujuan untuk mengkaji pengetahuan pasien yang menggunakan terapi komplementer obat tradisional tentang perawatan hipertensi. Jenis penelitian ini adalah deskriptif. Populasi penelitian merupakan pasien hipertensi yang menjalani terapi komplementer obat tradisional sejumlah 33 responden di Puskesmas Pejeruk. Sampling dengan tehnik non probability sampling yaitu total sampling. Pengambilan data pengetahuan responden tentang perawatan hipertensi menggunakan lembar kuesioner dengan wawancara langsung. Penelitian ini menghasilkan bahwa responden yang memiliki pengetahuan baik sebesar 57,6\%; responden yang memiliki pengetahuan cukup 36,4\% dan responden yang memiliki pengetahuan kurang $6,1 \%$. Kesimpulan penelitian ini adalah pengetahuan sebagian responden yaitu pasien hipertensi yang menggunakan terapi komplementer obat tradisional, tentang perawatan hipertensi termasuk dalam
\end{abstract}


kategori baik. Saran bagi puskesmas Pejeruk untuk tetap mempertahankan dan meningkatkan pendidikan kepada masyarakat tentang perawatan hipertensi dan pencegahan penyakit sedini mungkin, melalui penyuluhan pada posyandu, internet dan media leafet, booklet dan flyer.

\section{Kata Kunci : Pengetahuan, Perawatan, Hipertensi}

\section{PENDAHULUAN}

Hipertensi adalah kondisi seseorang mengalami kenaikan tekanan darah di atas normal, berakibat pada meningkatnya angka kesakitan (morbiditas) dan angka kematian/ mortalitas, tekanan darah lebih dari 140/90 mmHg berdasarkan fase sistolik( fase darah yang sedang dipompa oleh jantung) 140 dan fase diastolic (fase darah yang kembali jantung) 90 dalam setiap denyut jantung (Triyanto, 2014). Hipertensi sering dijuluki sebagai silent killer.

Data yang diperoleh dari National Center of Health Statistics (NCHC, 2017), prevalensi hipertensi pada penduduk umur $\geq 18$ tahun di Amerika Serikat pada tahun 2015-2016 sebesar 29,0\%, tapi hampir sekitar 90-95\% kasus dengan penyebab yang tidak diketahui dan diperkirakan akan meningkat menjadi 1,15 milyar kasus di tahun 2025. Data yang diperoleh dari Riset Kesehatan Dasar (Riskesdas, 2018), prevalensi hipertensi di Indonesia sebesar 34,1\%, dimana prevalensi hipertensi di NTB (24,3\%). Data yang diperoleh dari Dinas Kesehatan Provinsi NTB (2017), dari 2.981.909 penduduk usia 18 tahun ke atas, sebanyak 100.114 jiwa (24,90\%) mengalami hipertensi dan prevalensi hipertensi di Kota Mataram 5.967 jiwa. Data kunjungan pasien hipertensi se-Puskesmas di Kota Mataram pada tahun 2018, tercatat Puskesmas Pejeruk menempati peringkat keenam dengan kasus hipertensi terbanyak setelah Puskesmas Pagesangan dan Puskesmas Ampenan. Namun Puskesmas Pejeruk merupakan satu-satunya puskesmas di Kota Mataram yang telah menjalankan program terapi komplementer obat tradisional.

Data yang diperoleh dari Profil Puskesmas Pejeruk, jumlah kejadian hipertensi pada tahun 2018 ditemukan sebanyak 482 jiwa. Hipertensi menempati peringkat kedua dari sepuluh penyakit tertinggi di Puskesmas Pejeruk pada tahun 2018. Data di ruang poli jamu Puskesmas Pejeruk, jumlah daftar peserta pengguna terapi komplementer obat tradisional pada tahun 2017 tercatat sebanyak 46 orang yang rutin menggunakan terapi obat tradisional. Kemudian mengalami penurunan pada tahun 2018 yaitu tercatat sebanyak 33 orang peserta pengguna terapi komplementer obat tradisional (Profil Puskesmas Pejeruk, 2018).

Studi pendahuluan yang dilakukan peneliti pada tanggal 16-17 Februari 2019 pada pasien yang mengalami hipertensi dan melakukan terapi komplementer obat tradisional didapatkan hasil, dari 10 orang, sebanyak 4 orang mengatakan jarang melakukan aktivitas fisik, sebanyak 5 orang mengatakan merokok, sebanyak 6 orang mengatakan tidak rutin melakukan kunjungan ke puskesmas untuk cek kesehatan atau cek tekanan darah, sebanyak 4 orang mengatakan memanfaatkan tanaman untuk obat untuk hipertensi dan sebanyak 4 orang mengatakan rutin mengkonsumsi obat tardisional dari puskesmas. Dengan demikian, kesimpulan dari studi pendahuluan tersebut adalah masih terdapat masyarakat yang belum mengetahui tentang perawatan hipertensi dan terapi komplementer obat tradisional.

Hipertensi disebabkan oleh konsumsi garam yang berlebihan, stress, malas gerak, obesitas dan merokok. Faktor risiko hipertensi yang tak bisa diubah adalah usia, riwayat penyakit hipertensi dalam 
keluarga, dan jenis kelamin. Faktor risiko yang bisa diubah meliputi kelebihan berat badan dan obesitas, kurang gerak, pola makan, kecanduan alkohol, stress, merokok, konsumsi obat-obatan tertentu (NSAID, obat flu, pil KB) (Swari, 2018). Dampak akibat peningkatan tekanan darah yang terus-menerus dalam jangka waktu yang lama (persisten) adalah rusaknya ginjal (gagal ginjal), jantung (penyakit jantung koroner), dan otak (menyebabkan stroke) bila tidak terdeteksi sejak dini dan mendapatkan pengobatan yang adekuat (Pusdatin, Kemenkes, 2014). Penderita hipertensi memiliki risiko untuk mengidap penyakit jantung dua kali lipat dan penyakit stroke delapan kali lipat dibandingkan orang normal (Widharto, 2009). Kerusakan pada pembuluh darah ginjal, jantung, dan otak serta peningkatan gagal ginjal, penyakit koronaria, gagal jantung, stroke, dan demensia dapat terjadi akibat dari hipertensi yang menetap (Katzung, 2007). Angka kematian yang tinggi (high case fatality rate) juga berdampak kepada penurunan kualitas hidup adalah kejadian akibat dari hipertensi (Sudarmako, 2008).

Pemerintah memiliki peran yang sangat besar untuk menurunkan kejadian hipertensi yang berkembang di masyarakat. Sasaran Rencana Pembangunan Jangka Menengah Nasional (RPJMN) 20152019 adalah turunnya prevalensi tekanan darah tinggi pada penduduk umur $\geq 18$ tahun dari $25,8 \%$ pada tahun 2013 menjadi 23,4\% pada tahun 2019 (Kementerian Kesehatan Republik Indonesia, 2016). Upaya pemerintah dalam mencapai target pengendalian penyakit hipertensi antara lain melalui upaya edukasi yang lebih intensif tentang pentingnya perawatan hipertensi dan melalui pengobatan tradisional dengan tujuan untuk meningkatkan mutu pelayanan kesehatan serta membina dan mengembangkan "self care" (pengobatan mandiri) dengan cara tradisional.

Upaya pemerintah dengan pengobatan tradisional dapat direalisasikan melalui program kegiatan "Јати Ехро" dalam rangka mengenalkan pengobatan tradisional yaitu penggunaan obat herbal yang telah lulus uji penelitian oleh Kementerian Kesehatan RI kepada masyarakat umum (Keputusan Menteri Kesehatan RI, 2003). Program Jати Expo ini sudah dijalankan oleh Puskesmas Pejeruk selama \pm 3 tahun, dimana salah satu kegiatan Puskesmas Pejeruk dalam menerapkan obat herbal melalui program Jamu Expo meliputi pemberian edukasi tentang perawatan hipertensi serta menerapkan terapi komplementer obat tradisional (Dinas Kesehatan Kota Mataram, 2018).

Puskesmas Pejeruk dalam menerapkan program terapi komplementer ini telah melakukan beberapa kegiatan seperti jamu roadshow, membina keluarga sebagai Tanaman Obat Keluarga (TOGA) Binaan, pelayanan jamu, serta percontohan TOGA di posyandu. Pada kegiatan pelayanan jamu, peserta program terapi komplementer ini dilakukan pemeriksaan kesehatan terlebih dahulu disertai dengan konsultasi kesehatan, pemberian pendidikan kesehatan (penkes) dan cara menerapkan terapi komplementer obat tradisional dimana peserta yang terdaftar dalam program ini selain mendapatkan pengobatan tradisional juga tetap diberikan edukasi (Profil Puskesmas Pejeruk, 2017). Penelitian ini bertujuan untuk menggambarkan pengetahuan pasien tentang perawatan hipertensi di Puskesmas Pejeruk.

\section{METODE}

Penelitian ini termasuk dalam penelitian deskriptif. Populasi penelitian adalah pasien hipertensi dengan terapi komplementer obat tradisional sebanyak 33 pasien di Puskesmas Pejeruk. Tehnik sampling 
menggunakan total sampling. Besar sampel adalah sejumlah 33 sampel. Data yang dikumpulkan adalah data primer dan data sekunder. Data primer terdiri atas karakteristik responden dan pengetahuan pasien mengenai perawatan hipertensi yang dikumpulkan melalui wawancara langsung kepada pasien dengan menggunakan kuesioner. Pengetahuan pasien mengenai perawatan hipertensi meliputi cara perawatan hipertensi, tujuan mempertahankan berat badan ideal atau melakukan diet pada pasien hipertensi, makanan yang tidak dianjurkan bagi pasien dengan hipertensi, manfaat mengurangi konsumsi garam pada pasien hipertensi, olahraga yang dapat dilakukan bagi pasien dengan hipertensi, lama latihan fisik yang teratur, alasan mengurangi konsumsi alkohol dan tembakau (rokok), cara menurunkan stress, pemeriksaan tekanan darah secara rutin, dan nama obat medis untuk penyakit hipertensi serta dosis obat hipertensi dan waktu yang tepat untuk mengkonsumsi obat hipertensi. Data tentang pengetahuan pasien mengenai perawatan hipertensi diolah secara deskriptif dan ditampilkan dalam tabel distribusi frekuensi.

\section{HASIL}

1. Karakteristik responden

Tabel 1. Karakteristik Responden di Wilayah Kerja Puskesmas Pejeruk, April 2019 (n=33)

\begin{tabular}{|c|c|c|c|c|}
\hline No & & Karakteristik & Frekwensi & $\%$ \\
\hline \multirow[t]{4}{*}{1.} & Umur & $36-45$ tahun & 1 & 3,04 \\
\hline & & 46-55 tahun & 11 & 33,33 \\
\hline & & 56-65 tahun & 10 & 30,30 \\
\hline & & $>65$ tahun & 11 & 33,33 \\
\hline \multirow[t]{2}{*}{2.} & Jenis Kelamin & Laki-laki & 7 & 21,22 \\
\hline & & Perempuan & 26 & 78,78 \\
\hline \multirow[t]{4}{*}{3.} & Pendidikan & Tidak Sekolah & 11 & 33,33 \\
\hline & & Pendidikan Dasar & 12 & 36,37 \\
\hline & & Pendidikan Menengah & 5 & 15,15 \\
\hline & & Perguruan Tinggi & 5 & 15,15 \\
\hline \multirow[t]{2}{*}{4.} & Pekerjaan & Bekerja & 11 & 33,33 \\
\hline & & Tidak Bekerja & 22 & 66,67 \\
\hline \multirow[t]{5}{*}{5.} & Lama & 2- 6 bulan & 3 & 9,09 \\
\hline & Mengidap hipertensi & $7-11$ bulan & 5 & 15,15 \\
\hline & & 1- 5 tahun & 18 & 54,55 \\
\hline & & 5-10 tahun & 6 & 18,18 \\
\hline & & $>10$ tahun & 1 & 3,03 \\
\hline \multirow[t]{2}{*}{6.} & Riwayat & Ada & 10 & 30,30 \\
\hline & hipertensi & Tidak ada & 23 & 69,70 \\
\hline
\end{tabular}

Dari tabel 1 diatas dapat dilihat bahwa umur responden hampir seluruhnya lebih dari 46 tahun, sebagian besar responden $(78,78 \%)$ berjenis kelamin perempuan, pendidikan yang terbanyak adalah pendidikan dasar $(36,37 \%)$, terbanyak tidak bekerja $(66,67 \%)$, sebagian responden mengidap hipertensi 1-5 tahun dan kebanyakan responden yaitu 69,70\% tidak memiliki riwayat keturunan hipertensi. 
2. Pengetahuan responden di wilayah Puskesmas Pejeruk tentang perawatan hipertensi

Tabel 2 : Pengetahuan tentang perawatan hipertensi di wilayah Puskesmas Pejeruk, April 2019 $(n=33)$.

\begin{tabular}{|c|c|c|c|}
\hline No. & Kategori & Frekuensi & $\%$ \\
\hline \multirow[t]{4}{*}{1.} & Pengetahuan tentang perawatan hipertensi & & \\
\hline & - Baik & 19 & 57,6 \\
\hline & - Cukup & 12 & 36,4 \\
\hline & - Kurang & 2 & 6,1 \\
\hline
\end{tabular}

Tabel di atas memperlihatkan bahwa tingkat pengetahuan responden tentang perawatan hipertensi yang paling banyak yaitu pada kategori baik berjumlah 19 responden (57,6\%), sedangkan kategori tingkat pengetahuan responden yang paling sedikit yaitu pada kategori kurang berjumlah 2 responden $(6,1 \%)$.

\section{PEMBAHASAN}

Hasil penelitian menunjukan bahwa pengetahuan responden tentang perawatan hipertensi yang paling banyak yaitu pada kategori baik dan pengetahuan responden yang paling sedikit yaitu pada kategori kurang. Pengetahuan responden mengenai perawatan hipertensi sebagian dalam kategori baik, dimana sebagian responden mampu melakukan modifikasi gaya hidup untuk mengatasi hipertensi. Menurut Priscilla \& Gerene (2015) perawatan dan usaha pencegahan hipertensi sejak dini sangatlah penting. Perawatan hipertensi adalah upaya-upaya dalam rangka menjaga tekanan darah supaya tetap dalam batas normal. Dengan perawatan yang tepat, hipertensi dapat diatasi secara tuntas. Menurut Priscilla \& Gerene (2015), adapun cara-cara perawatan pasien hipertensi yaitu melakukan modifikasi gaya hidup dengan diet, mengurangi asupan garam, melakukan aktivitas fisik, mengurangi konsumsi alkohol, berhenti merokok, mengendalikan stress, melakukan pemeriksaan tekanan darah secara rutin dan dengan medikasi.

Hasil penelitian ini didapatkan bahwa dari 19 responden dengan pengetahuan yang baik, terdapat 33 responden (100\%) mengetahui cara perawatan hipertensi, 27 responden $(81,8 \%)$ mengetahui tujuan mempertahankan berat badan, 30 responden $(90,9 \%)$ mengetahui makanan yang tidak dianjurkan pasien hipertensi, 32 responden $(96,9 \%)$ mengetahui manfaat mengurangi garam, 33 responden (100\%) mengetahui olah raga untuk pasien hipertensi, 26 responden $(78,8 \%)$ mengetahui waktu latihan fisik untuk hipertensi, 29 responden (87,8\%) mengetahui dampak alkohol dan rokok bagi pasien hipertensi dan 33 responden (100\%) mengetahui cara untuk menurunkan stress. Namun hanya 17 responden $(51,5 \%)$ mengetahui pemeriksaan tekanan darah secara rutin, 23 responden (69,7\%) mengetahui nama obat medis, 19 responden $(57,57 \%)$ mengetahui dosis untuk hipertensi, dan sebanyak 18 responden $(54,54 \%)$ mengetahui waktu yang tepat mengkonsumsi obat hipertensi. Dari data di atas dapat diketahui bahwa responden yang berpengetahuan baik mengetahui tentang modifikasi gaya hidup dan responden yang berpengetahuan kurang yaitu tentang pemeriksaan tekanan darah secara rutin serta perawatan dengan medikasi seperti nama obat, dosis dan waktu minum obat. 
Banyak faktor yang mempengaruhi hasil penelitian ini. Menurut Notoatmodjo (2012), faktorfaktor yang mempengaruhi pengetahuan yaitu pendidikan, umur, pekerjaan dan faktor eksternal lainnya. Umur mempengaruhi pengetahuan, menurut pendapat Budiman (2013) dikutip dari penelitian Marlita (2013) yang menyatakan bahwa usia mempengaruhi daya tangkap dan pola pikir seseorang. Dengan bertambahnya usia seseorang menyebabkan semakin berkembangnya daya tangkap dan pola pikirnya sehingga pengetahuan yang didapat semakin meningkat juga. Namun menurut pendapat Cropton, J (1997) dikutip dari penelitian Aulia (2013) yang menyatakan bahwa usia produktif merupakan usia dewasa yang aktif dalam kegiatan sehingga mendukung dalam belajar dan mengingat informasi yang diperoleh, akan tetapi pada umur-umur tertentu atau menjelang usia lanjut kemampuan penerimaan atau mengingat suatu pengetahuan akan berkurang.

Hasil penelitian ini menunjukkan dari 19 responden yang berpengetahuan baik dimana 1 responden $(5,3 \%)$ berumur $36-45$ tahun, 8 responden $(42,1 \%)$ berumur $46-55$ tahun, 4 responden $(21,1 \%)$ berumur 56-65 tahun, dan 6 responden $(31,6 \%)$ berumur $>65$ tahun. Dengan demikian lebih dari sebagian responden yang memiliki pengetahuan baik adalah lansia. Penelitian ini sejalan dengan pendapat Marlita (2013), dimana pengetahuan semakin baik karena daya tangkap dan pola pikir yang semakin berkembang dengan semakin bertambahnya usia seseorang. Hal ini dibuktikan dari hasil penelitian yang menunjukkan dari 19 responden berpengetahuan baik hampir sebagian berumur 46-55 tahun $(42,1 \%)$. Menurut peneliti lansia awal memiliki pengetahuan baik karena pengetahuan yang dimilikinya bisa berasal dari pengetahuan sebelumnya yang berasal dari pengalaman atau sumber informasi dari petugas kesehatan. Namun karena sebagian besar responden adalah lansia, jadi tidak menutup kemungkinan bahwa penelitian ini juga sejalan dengan pendapat Aulia (2013) yang mengatakan bahwa kemampuan penerimaan atau mengingat suatu pengetahuan akan berkurang pada umur-umur tertentu atau menjelang usia lanjut. Dibuktikan dari hasil penelitian yang menunjukkan dari 14 responden berpengetahuan cukup dan kurang, sebagian besar responden berumur $>65$ tahun sebanyak 8 responden $(57,2 \%)$. Dengan demikian, umur dapat mempengaruhi pengetahuan seseorang. Dengan meningkatnya usia maka semakin banyak pengalaman yang didapat sehingga pengetahuan semakin baik, namun kemampuan atau mengingat suatu pengetahuan akan berkurang menjelang usia lanjut.

Hasil penelitian responden menurut pendidikan tertinggi berada pada tingkat pendidikan dasar yaitu 12 responden (36,3\%). Dimana responden dengan pengetahuan baik sebagian besar berada pada tingkat pendidikan dasar sebanyak 6 (31,6\%). Hal ini sejalan dengan pendapat Notoatmodjo (2012) bahwa "pendidikan adalah suatu usaha untuk mengembangkan kepribadian dan kemampuan didalam dan diluar sekolah yang berlangsung seumur hidup". Selain dari pendidikan formal, dapat diperoleh melalui orang lain maupun media massa antara lain majalah, televisi, surat kabar, dan radio. Dan seseorang dengan pendidikan rendah bukan berarti mutlak memiliki pengetahuan yang rendah pula. Namun pendapat lain mengatakan bahwa dengan pendidikan yang semakin tinggi maka seseorang akan semakin mudah menerima informasi sehingga semakin meningkat pula pengetahuan yang dimilikinya (Carter, 2011). Menurut pendapat peneliti, hasil penelitian ini sesuai dengan pendapat Notoatmodjo (2012) dimana pengetahuan bisa didapat selain melalui pendidikan formal dalam sekolah namun juga bisa diperoleh dari pendidikan nonformal di luar sekolah dan melalui pengalaman. Walaupun responden 
berada pada mayoritas berpendidikan rendah maka bukan berarti mutlak berpengetahuan rendah pula. Pendidikan tidak mempengaruhi pengetahuannya sebab responden dengan pengetahuan baik dapat memperoleh informasi dari pengalaman atau orang lain maupun media masa.

Karakteristik dari segi pekerjaan responden terbanyak adalah tidak bekerja yaitu sejumlah 22 responden $(66,7 \%)$, dan yang terendah petani/buruh $1(3,1 \%)$. Responden dengan pengetahuan baik sebagian besar merupakan tidak bekerja sebanyak 12 (63,2\%). Notoatmodjo (2012) dengan memiliki pekerjaan maka banyak waktu akan diperlukan untuk hal tersebut yang dianggap penting memerlukan perhatian masyarakat, maka waktu untuk memperoleh informasi menjadi sedikit, pada akhirnya pengetahuan mereka menjadi berkurang. Pengetahuan dan pengalaman seseorang dipengaruhi oleh pekerjaan, karena saat pekerjaan lebih sering menggunakan otak maka kemampuan otak terutama dalam menyimpan (daya ingat) akan bertambah ketika sering dipakai sehingga pengetahuannya menjadi baik (Pangesti, 2012). Penelitian ini didapatkan bahwa sebagian besar responden tidak bekerja atau hanya menjadi ibu rumah tangga. Hal ini menunjukkan bahwa responden yang tidak bekerja mempunyai banyak waktu luang untuk mendapatkan informasi, baik itu sumber informasi bisa diperoleh melalui majalah, koran, televisi, radio, maupun internet sehingga dapat menambah pengetahuannya tentang perawatan hipertensi. Selain itu, penyuluhan oleh mahasiswa atau petugas kesehatan seringkali dihadiri oleh warga yang tidak bekerja. Hal ini diperkuat oleh pernyataan dari petugas kesehatan di puskesmas Pejeruk ketika kegiatan penyuluhan itu berlangsung.

Karakteristik sumber informasi, didapatkan responden tertinggi yang mendapatkan sumber informasi melalui petugas kesehatan sejumlah 22 responden (66,7\%). Dengan sebagian besar responden yang berpengetahuan baik dengan sumber informasi melalui petugas kesehatan sebanyak 11 (57,9\%). Hasil penelitian ini sesuai dengan pernyataan Notoatmodjo (2003) dalam Titik (2015) mengatakan pengetahuan adalah hasil dari tahu, yang terjadi setelah obyek tertentu dilakukan pengindraan oleh seseorang. Penginderaan dilakukan oleh panca indra manusia, yakni penglihatan, pendengaran, penciuman, rasa dan raba. Mata dan telinga adalah sumber penginderaan sebagian besar pengetahuan manusia. Dengan demikian penggunaan panca indera sangat penting terhadap suatu informasi. Sesuai juga dengan penelitian Hananditia \& Nina (2016), pengetahuan yang baik dapat dipengaruhi oleh banyak faktor antara lain pengalaman dan sarana informasi. Pengetahuan juga dapat diperoleh dari wahana informasi di rumah yaitu radio dan televisi.

Petugas kesehatan, menurut peneliti adalah orang yang sangat memegang peranan penting dalam upaya meningkatkan pengetahuan pasien tentang perawatan hipertensi karena petugas kesehatan merupakan tenaga terampil dan terlatih yang bertemu langsung dengan pasien. Petugas kesehatan dapat menambah pengetahuan pasien mengenai perawatan hipertensi terkait modifikasi gaya hidup, cek tekanan darah secara rutin, serta medikasi. Kontribusi petugas kesehatan tidak hanya memberikan pengetahuan tentang perawatan hipertensi namun juga memberikan informasi mengenai penyakit hipertensi dan komplikasi. Dalam penelitian ini, diperoleh tingkat pengetahuan yang baik. Hal ini didukung dengan adanya penyuluhan kesehatan, ketersediannya posyandu lansia, posbindu dan prolanis, memberikan brosur tentang penyakit hipertensi serta motivasi-motivasi lainnya yang diberikan petugas kesehatan kepada responden. Hal ini dibuktikan dari pernyataan petugas kesehatan di puskesmas Pejeruk ketika 
kegiatan penyuluhan itu berlangsung. Hasil penelitian ini didukung oleh penelitian dari Dedi Hartadi (2017) tentang perawatan hipertensi, yang judul "Pengetahuan dan sikap lansia tentang perawatan Hipertensi di Puskesmas Karang Taliwang Kota Mataram” yang menunjukkan bahwa dari 36 responden terdapat 21 responden $(58,3 \%)$ dikategorikan baik mengenai pengetahuan perawatan hipertensi sedangkan yang 8 responden memiliki pengetahuan yang kurang mengenai perawatan hipertensi.

\section{KESIMPULAN}

Sebagian besar responden hipertensi yang menggunakan terapi komplementer obat tradisional di Puskesmas Pejeruk memiliki pengetahuan yang baik tentang perawatan hipertensi. Peneliti merekomendasikan pelaksanaan terapi komplementer obat tradisional dapat ditingkatkan melalui program puskesmas.

\section{DAFTAR PUSTAKA}

Booth, A. O., \& Nowson, C. A. (2010). Patient recall of receiving lifestyle advice for overweight and hipertension from their general practitioner. BMC Family Practice, 11 (8). Doi: 10.1186/1471229-11-8.

Brunner \& Suddarth, 2016. Keperawatan Medikal Bedah. Edisi 12. Jakarta : EGC

Carter, William K. 2011. Akuntansi Biaya. Penerjemah : Krista, Buku 1, Edisi Ketiga Belas, Salemba Empat, Jakarta.

Departemen Kesehatan RI. 2009. Katgori Usia. Dalam http://kategori-umur-menurut-Depkes.html. Diakses tanggal 6 Maret 2019.

Departemen Kesehatan RI, 2017. Sebagian Besar Penderita Hipertensi Tidak Menyadarinya. Jakarta : Kementerian Kesehatan RI

Dinas Kesehatan Provinsi Nusa Tenggara Barat, 2017. Profil Kesehatan Provinsi NTB Tahun 2017. Mataram : Dinas Kesehatan Provinsi Nusa Tenggara Barat.

Dinas Kesehatan Kota Mataram, 2018. Profil Kesehatan Kota Mataram Tahun 2018. Mataram : Dinas Kesehatan Kota Mataram.

Hananditia \& Nina. 2016. Tingkat Pengetahuan Pasien Hipertensi Tentang Penggunaan Obat di Puskesmas Kota Malang. Jurnal Farmasi Klinik Indonesia. Malang : Universitas Brawijaya.

Kemenkes RI, 2014. Infodatin Pusat Data dan Informasi Kementerian Kesehatan RI 2014. Jakarta : Kementerian Kesehatan Republik Indonesia.

Kemenkes RI, 2016. Laporan Hasil Survei Indikator Kesehatan Nasional (Sirkesnas) 2016. Jakarta : Kementerian Kesehatan Republik Indonesia.

Kemenkes RI, 2018. Pengendalian Penyakit Tidak Menular (P2PTM). Jakarta : Kementerian Kesehatan Republik Indonesia.

Kartika, S. W. 2013. Standar Asuhan Keperawatan. Jakarta : TIM.

Katzung, B.G., 2007, Vasodilator \& Terapi Angina Pektoris, dalam Katzung, B.G., Farmakologi Dasar \& Klinik (Basic \& Clinical Pharmacology), edisi 10, Penerbit Buku Kedokteran, EGC, Jakarta 
NCHC, 2017. Hypertension Prevalence and Control Among Adults : United States, 20152016. Diakses melalui : https://www.cdc.gov/nchs/ products/ databriefs.htm diakses pada tanggal 6 Februari 2019.

Nursalam, 2017. Metodologi Penelitian Ilmu Keperawatan : Pendekatan Praktis. Jakarta : Salemba Media

Notoatmodjo, S. 2012. Promosi Kesehatan dan Perilaku Kesehatan. Jakarta : PT Rineka Cipta.

Pangesti, N. A. 2012. Gambaran karakteristik wanita usia subur (WUS) yang melakukan pemeriksaan inspeksi visual asam asetat (IVA) di Puskesmas Karanganyar. Jurnal Ilmiah Kesehatan Keperawatan, volume 8 (2), 81-94.

Perhimpunan Dokter Spesialis Kardiovaskular Indonesia (PERKI). 2015. Pedoman Tatalaksana Hipertensi Pada Penyakit Kardiovakular. Jakarta : PERKI

Putra A. W. 2017. Faktor-faktor Yang Mempengaruhi Tingkat Pengetahuan Masyarakat dalam Mitigasi Bencana Alam Tanah Longsor. Skripsi. Magelang : STIKes Muhammadiyah Gombong.

Priscilla, K. \& Gerene, 2015. Buku Ajar Keperawatan Medikal Bedah. Edisi 5. Jakarta : EGC.

Prastutie Hananditia \& Silviana Nina. 2016. Tingkat Pengetahuan Pasien Hipertensi tentang Penggunaan Obat di Puskesmas Kota Malang. Jurnal Farmasi Klinik Indonesia. Malang : Universitas Brawijaya.

Profil Puskesmas Pejeruk, 2017.

Profil Puskesmas Pejeruk, 2018.

Putri, D. M. P. 2016. Pengantar Riset Keperawatan. Yogyakarta: Pustaka Baru Press

Rahayu. 2010. Faktor Yang Mempengaruhi Penegetahuan. Diakses Melalui : https://www.google.com/url?sa=t\&source=web\&rct=j\&url=http://rep ository.umy.ac.id/bitstream/handle/123456789/2525/6.\%2520BAB \%2520II.pdf\%3Fsequence\%3D6\%26isAllowed\%3Dy\&ved=2ahUK EwiBorfrrjgAhUHiHAKHTwpB20QFjAAegQIARAB\&usg=AOvVaw3LWd- MEImCidGDgoXZW1yG diakses pada tanggal 6 Februari 2019 pukul 21.00.

Ridjab, Denio A. 2007. Modifikasi Gaya Hidup dan Tekanan Darah Tinggi. Majalah Kedokteran Indonesia. Jakarta : Universitas Katolik Atma Jaya.

Riskesdas, 2018. Hasil Utama RISKESDAS 2018. Diterbitkan oleh Badan Penelitian dan Pengembangan Kesehatan. Diakses pada tanggal 10 Januari 2018 pukul 01.43 WITA.

Rian A. P. Dan Andi M. U., 2017. Metodologi Riset Keperawatan. Jakarta Timur : Trans Info Media.

Sudarmoko A,2008. Tetap Tersenyum Melawan Hipertensi. Atma Media Press

Suranti, I, 2017. Pengaruh Brisk Walking Exercise Terhadap Penurunan Tekanan Darah Pada Pasien Hipertensi Di Puskesmas Andalas Kota Padang Tahun 2016. Skripsi. Padang : Universitas Andalas.

Setiadi. 2013. Konsep dan Praktik Penulisan Riset Keperawatan. Graha Ilmu. Yogyakarta.

Swari, R.C. 2018. Berbagai Penyebab Hipertensi Yang Harus Anda Ketahui., reviewer dan editor : dr. Damar Upahita. Diakses dari https://hellosehat.com/pusat-kesehatan/hipertensi-tekanan-darahtinggi pada tanggal 18 Oktober 2019 pukul 12.20 WITA. 
Pusdatin Kemenkes RI. 2014. Hipertensi. Pusat Data dan Informasi Kemenkes RI.

Titik, L, 2015. Kumpulan Teori Untuk Kajian Pustaka Penelitian Kesehatan. Yogyakarta : Nuha Medika

Triyanto, E, 2014. Pelayanan Keperawatan Bagi Penderita Hipertensi Secara Terpadu. Yogyakarta: Graha Ilmu.

Undang-Undang RI. 2003. Sistem Pendidikan Nasional. Presiden Republik Indonesia.

Usman, Husaini \& Purnomo S. A., 2008. Metodologi Penelitian Sosial.Jakarta : PT. Bumi Aksara.

Wawan dan Dewi, 2010. Teori dan Pengukuran Pengetahuan, Sikap dan Perilaku Manusia. Yogyakarta : Nuha Medika.

Widharto. 2009. Bahaya Hipertensi. Sunda Kelapa Pustaka.Jakarta. Divine, Jon G. 2012. Program Olahraga Tekanan Darah Tinggi. PT Citra Aji Parama. Yogyakarta. 